\title{
Microfossils from the Lower Devonian Rhynie Chert with Suggested Affinities to the Peronosporomycetes
}

\author{
Author(s): Michael Krings, Thomas N. Taylor, Edith L. Taylor, Hans Kerp, Hagen Hass, Nora Dotzler, \\ and Carla J. Harper \\ Source: Journal of Paleontology, 86(2):358-367. 2012. \\ Published By: The Paleontological Society \\ DOI: http://dx.doi.org/10.1666/11-087.1 \\ URL: http://www.bioone.org/doi/full/10.1666/11-087.1
}

BioOne (www.bioone.org) is a nonprofit, online aggregation of core research in the biological, ecological, and environmental sciences. BioOne provides a sustainable online platform for over 170 journals and books published by nonprofit societies, associations, museums, institutions, and presses.

Your use of this PDF, the BioOne Web site, and all posted and associated content indicates your acceptance of BioOne's Terms of Use, available at www.bioone.org/page/terms_of_use.

Usage of BioOne content is strictly limited to personal, educational, and non-commercial use. Commercial inquiries or rights and permissions requests should be directed to the individual publisher as copyright holder. 


\title{
MICROFOSSILS FROM THE LOWER DEVONIAN RHYNIE CHERT WITH SUGGESTED AFFINITIES TO THE PERONOSPOROMYCETES
}

\author{
MICHAEL KRINGS $, 1,2$ THOMAS N. TAYLOR, ${ }^{2}$ EDITH L. TAYLOR, ${ }^{2}$ HANS KERP, ${ }^{3}$ HAGEN HASS,${ }^{3}$ \\ NORA DOTZLER, ${ }^{1}$ AND CARLA J. HARPER ${ }^{2}$ \\ ${ }^{1}$ Department für Geo- und Umweltwissenschaften, Paläontologie und Geobiologie, Ludwig-Maximilians-Universität, and Bayerische Staatssammlung \\ für Paläontologie und Geologie, Richard-Wagner-Straße 10, \\ Munich 80333, Germany, <m.krings@lrz.uni-muenchen.de>; <n.dotzler@lrz.uni-muenchen.de>; ${ }^{2}$ Department of Ecology and Evolutionary Biology, \\ and Natural History Museum and Biodiversity Institute, University of Kansas, Lawrence KS 66045-7534, USA, \\ <tntaylor@ku.edu>; < etaylor@ku.edu>; < charper@ku.edu>; and ${ }^{3}$ Forschungsstelle für Paläobotanik am Geologisch-Paläontologischen Institut, \\ Westfälische Wilhelms-Universität Münster, Hindenburgplatz 57, Münster 48143, Germany, <hagenhass@web.de>; < kerp@uni-muenster.de>
}

\begin{abstract}
A conspicuous silicified microfossil, Frankbaronia polyspora n. gen. n. sp., occurs in plant litter and as an inhabitant of microbial mats from the Lower Devonian Rhynie chert, Aberdeenshire, Scotland. Specimens are elongate-cylindrical, oval, or spherical, thin-walled, and may possess conical or column-like surface projections. Most specimens occur isolated, some are arranged in pairs or short chains. Each specimen contains several small spheres, each in turn with a (sub)centric opaque inclusion. Immature specimens indicate that ontogenesis in this fossil includes the formation of a single centric body of opaque material that subsequently is apportioned among the developing small spheres. Frankbaronia polyspora is quite similar in size and morphology to the oogonia containing oospores seen in certain extant members of the Peronosporomycetes. The Rhynie chert is known to contain the oldest fossil evidence of the Peronosporomycetes but only a single form (Hassiella monospora) has previously been documented. The discovery of a second putative representative of this group of organisms proves that this paleoecosystem is still an important source of new information on the paleodiversity of microbial life.
\end{abstract}

\section{INTRODUCTION}

$I_{\mathrm{k}}^{\mathrm{N}}$ $\mathrm{N}$ THE one hundred years since the famous Rhynie chert Konservat-Lagerstätte was discovered in Aberdeenshire, Scotland, there has been an exceptionally large and diverse assemblage of organisms described. Among the most interesting life forms inhabiting this Early Devonian hot spring ecosystem are several types of structurally preserved early land plant sporophytes and gametophytes that have been instrumental in advancing our understanding of the early evolution of vascular plants on land (surveyed in Kerp and Hass, 2004, 2009). Equally important has been the detailed documentation of animal life from the Rhynie paleoecosystem (surveyed in Trewin and Fayers, 2004).

In recent years there has been renewed interest in the microbial component of the Rhynie paleoecosystem, inspired in part by the increasing awareness of the importance of microorganisms as drivers and sustainers in modern ecosystems (Taylor et al., 2004). As a result, there have been several different types of microorganisms identified, including fungi belonging to the Chytridiomycota (e.g., Taylor et al., 1992; Krings et al., 2009a), Blastocladiomycota (Remy et al., 1994), Glomeromycota (e.g., Taylor et al., 1995; Dotzler et al., 2009), and Ascomycota (Taylor et al., 2005), several examples of green algae (Edwards and Lyon, 1983; Dotzler et al., 2007) and cyanobacteria (Kidston and Lang, 1921; Croft and George, 1959; Krings et al., 2007, 2009b), as well as one representative of the fungus-like Peronosporomycetes (Taylor et al., 2006). What is perhaps most remarkable about the Rhynie chert is that many of the microorganisms are preserved in close association with one another or with other elements of the ecosystem; some forms even display various degrees of parasitic or mutualistic interactions. When compared to extant equivalents, the affinities of many of the Rhynie chert microorganisms can be accurately determined based on structural features; others, however, remain difficult and sometimes even impossible to place systematically.

Within certain aquatic facies of the Rhynie chert are accumulations of plant debris and conspicuous microbial mats dominated by a filamentous cyanobacterium, Croftalania venusta Krings et al. (2007). Associated with both plant debris and $C$. venusta-dominated microbial mats are various types of other microorganisms, including fungal hyphae and what appear to be unicellular and filamentous algae. Other associated microorganisms include the conspicuous microfossils that are the focus of this paper, and which we attribute to the Peronosporomycetes (Oomycota).

\section{GEOLOGICAL SETTING, MATERIALS AND METHODS}

The Rhynie chert is located in the northern part of the Rhynie Outlier of Lower Old Red Sandstone in Aberdeenshire, Scotland, within a sequence of sedimentary and volcanic rocks. The cherts occur in the upper part of the Dryden Flags Formation, in the so-called Rhynie Block, located a few hundred meters northwest of the village of Rhynie. The Lagerstätte consists of fossiliferous beds containing lacustrine shales and cherts that have been interpreted as a series of ephemeral freshwater pools within a hot spring environment (Rice et al., 2002; Rice and Ashcroft, 2004). Preserved in the cherts are both aquatic (freshwater) facies from the pools and subaerial soil/litter horizons with in situ plants that occupied the edges of the pools; it is hypothesized that the latter became preserved as a result of temporary flooding of silica-rich water, or by silica-rich groundwater that percolated to the surface. The cherts have been dated as Pragian-?earliest Emsian based on dispersed spore assemblages (Wellman, 2006; Wellman et al., 2006). A recent high-precision $\mathrm{U}-\mathrm{Pb}$ age constraint on the Rhynie Lagerstätte indicates an absolute age of $411.5 \pm$ 1.3 Ma (Parry et al., 2011). Details about the geological setting, sedimentology, and development of the Rhynie chert Lagerstätte can be found in Rice et al. (2002), Rice and Ashcroft (2004), and Trewin and Rice (2004).

The microfossils were identified in thin sections prepared from two chert blocks by cementing a thin wafer of the chert to a glass slide and then grinding the rock slice with silicon carbide powder until sufficiently thin to transmit light. The 
specimens were examined and photographed using oil immersion objectives directly on the rock surface without a cover slip. Slides are deposited in the collection of the Forschungsstelle für Paläobotanik am Institut für Geologie und Paläontologie, Westfälische Wilhelms-Universität, Münster (Germany), under accession numbers P2180, P2181, and P3901-P3929.

\section{SYSTEMATIC PALEONTOLOGY}

Kingdom StraminipILA M. W. Dick, 2001

Phylum HeTEROKONTA Cavalier-Smith, 1986

Subphylum PeronosporomycotinA M. W. Dick, 2001

Class Peronosporomycetes M. W. Dick, 2001

Order uncertain

Genus FrankBARONIA new genus

Type species.-Frankbaronia polyspora n. gen. n. sp., by monotypy

Diagnosis.-Fossil organism; oogonia in terminal or intercalary position, variable in size and shape, polyoosporous; oogonium wall smooth or with one to multiple prominent projections arising from surface; oospores thin-walled, each with a (sub)centric opaque inclusion (ooplast).

Etymology.-The genus name is proposed in honor of Dr. Frank Baron, Professor at the Department of Germanic Languages and Literatures, University of Kansas, for his long term support of our work on fossil microorganisms.

\section{FRANKBARONIA POLYSPORA new species} Figures 1-3

Diagnosis.-Oogonium elongate-cylindrical, ovoid, or spherical in shape, usually $\leq 50 \mu \mathrm{m}$ wide or in diameter; oogonium wall relatively thin, smooth or with irregularly distributed conical or column-like hollow projections; oogonium containing between 3 and 40 (but $>80$ in very large specimens) smooth-walled oospores; developing oospores arranged around single oosphere- or coenocentrum-like structure in centre of oogonium.

Holotype.-Specimen illustrated in Figure 1.6 of this paper; slide P3921, deposited in the collection of the Forschungsstelle für Paläobotanik am Institut für Geologie und Paläontologie, Westfälische Wilhelms-Universität, Münster, Germany.

Paratypes.-Specimens illustrated in Figures 1.10 (slide P3925) and 2.1 (slide P3911), deposited in the collection of the Forschungsstelle für Paläobotanik am Institut für Geologie und Paläontologie, Westfälische Wilhelms-Universität, Münster, Germany.

Etymology.-The epithet polyspora refers to the multiple oospores per oogonium.

Occurrence.-Rhynie, Aberdeenshire, Scotland, National Grid Reference NJ 494276. Age is Early Devonian (Pragian?earliest Emsian), according to palynomorphs (Wellman, 2006; Wellman et al., 2006); $411.5 \pm 1.3 \mathrm{Ma}$ based on U-Pb dating (Parry et al., 2011).

Description (morphology).- - Scattered throughout the accumulations of plant litter and Croftalania venusta-dominated microbial mats are conspicuous microfossils (Figs. 1-3), which may be elongate-cylindrical (up to $120 \mu \mathrm{m}$ long and $50 \mu \mathrm{m}$ wide) (Fig. 2.3, 2.4), ovoid (up to $90 \mu \mathrm{m}$ long and $<50(-70) \mu \mathrm{m}$ wide) (Fig. 1.10, 1.11), or, most often, spherical or drop-shaped (up to $50(-65) \mu \mathrm{m}$ in diameter) (Figs. 1.1-1.3, 1.6-1.9, 2.1, 2.5. 2.6, 2.8, 3.1-3.3); more than 100 specimens of this type of fossil have been discovered. The specimens may be solitary (Figs. 1.6-1.11, $2.5,2.6$ ), arranged in pairs or short chains (Figs. 1.4, 1.5, 2.12.4), or occur in loose clusters of up to 20 individuals (Fig. 1.11.4). The outer wall of the microfossils is relatively thin and in some cases smooth (e.g., Fig. 2.3, 2.4), while in others there may be a few (e.g., Fig. 1.10, 1.11) to several (e.g., Fig. 1.6, 1.8), irregularly distributed hollow projections extending from the wall. Projections are up to $10 \mu \mathrm{m}$ high and morphologically may be pore- to column-like with an open tip, papilla-shaped, or pointed. The open tips of the pore- to column-like projections (e.g., Fig. 1.9, 1.11, arrows) suggest that these structures were larger and/or more complex in vivo. Two of the specimens appear to be attached to a relatively narrow subtending hypha or filament (Fig. 2.5, 2.6, arrows); moreover, in a few others there are large orifices that might represent the attachment points of wider parental hyphae (Fig. 1.7, 1.8, between the arrows). Specimens may be empty (Fig. 1.4) or secondarily infected by some type of microfungi (Fig. 1.5), but most often they contain several (usually between 10 and 40, but only 3 to 5 in very small [Fig. 2.6] and $>80$ in the largest [Fig. 2.4] specimens) small spheres that are smooth and bounded by a thin but distinct wall; these spheres vary in diameter from $(<10-)$ $10-15(-20) \mu \mathrm{m}$. Each of the interior spheres in turn contains a well-defined, uniform (sub)centric opaque inclusion that appears to be entirely separate from the wall of the sphere (e.g., Figs. 1.6, 1.9, 2.1); there are only a few specimens in which the interior spheres lack a distinct central opaque inclusion (e.g., Fig. 1.7). In some specimens, the central inclusion is distinctly more opaque around the periphery (Figs. 2.8, 3.3). In two specimens (Fig. 2.7, 2.8, arrows), short hyphal fragments up to $3 \mu \mathrm{m}$ wide are attached to one or several of the interior spheres. In one of these specimens, however, the interior sphere with a hyphal appendage differs from the other interior spheres in that it lacks an opaque inclusion (Fig. 2.7). The interior spheres contained in the second specimen (Fig. 2.8) differ from the interior spheres in other specimens in that the opaque inclusions are much larger in relation to the sphere diameter. Moreover, the wall of the interior spheres in this specimen is irregular or appears wrinkled.

Most specimens occur singly or in loose clusters but there are also a few instances in which several structures are arranged in a pair (Fig. 1.5) or short chain (Fig. 1.1-1.4). One of the chains (Fig. 2.1) shows three spherical structures, each containing numerous small spheres, that are attached to one another. The contact area between the upper and middle structure (Fig. 2.1, arrow) indicates that they were completely separated from one another and held together by mucilage or a short hyphal segment. Focusing through the middle and lower unit, however, reveals that these two structures are organically connected (Fig. 2.2). Another chain is irregular and consists of two elongate structures filled with interior spheres and several smaller, spherical swellings that are empty (Fig. 2.3 and 2.4).

Description (development).--Perhaps the most interesting aspect with regard to this microfossil are specimens revealing stages of development of the interior spheres (Fig. 3.1-3.3). It appears that in one developmental stage a large mass of opaque material (not bounded by a wall) forms in the center of the parental structure, and that this mass subsequently is apportioned radially and redistributed to the individual small spheres. This pattern is best viewed from the specimen illustrated in several focal planes in Figure 3.1a-f. In this fossil, several developing small spheres are visible (arrows) in which the individual walls are already well-recognizable, but the inclusions still are connected to the mass of opaque material in the centre of the parental structure. The two specimens illustrated in Figure 3.2 show a similar configuration, which indicates that this process of material redistribution was consistent. In a later stage of development, the inclusions of 


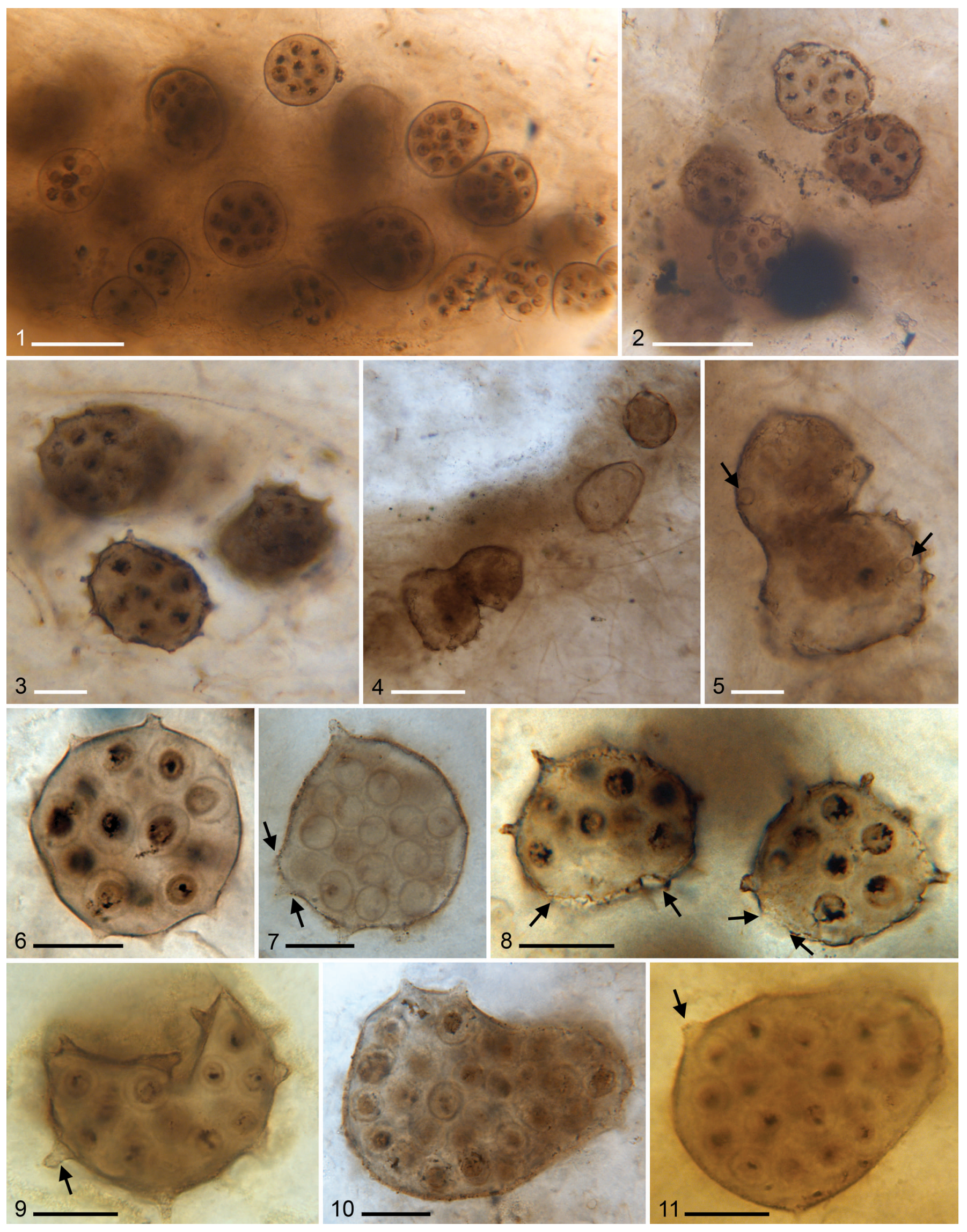


the individual small spheres are still connected to the center by a narrow, thread-like structure (Fig. 3.3a, 3.3b, arrows). Eventually, however, the inclusions become separated and the walls are closed. It is impossible to determine whether the entire mass of opaque material is distributed to the individual small spheres, or some of the material remains in the centre of the parental structure.

Remarks.-We use the spelling Straminipila, rather than Stramenopila, as the former is the validly published name for this kingdom (Dick, 2001; Lévesque, 2011) (see discussion in Beakes and Sekimoto [2009]). We formally assign the fossils to the Peronosporomycetes based on morphological features of what are interpreted as oogonia containing oospores (see Discussion below). It is currently impossible to further delimit the affinities of the fossils within this class, and therefore we do not resolve the ranks below class. Moreover, nothing is known about the range of morphological plasticity of the fossil peronosporomycetes. Thus, we cannot rule out that the structures described in this paper under the name Frankbaronia polyspora represent several morphologically similar species. Oogonium morphology in extant peronosporomycetes may be highly variable within species (Dick, 2001). Our set of $>100$ specimens of $F$. polyspora includes numerous intermediate morphologies that range from spherical to elongate (e.g., Fig. 1.11), as well as lack of ornamentation to prominently ornamented (e.g., Fig. 1.7). We therefore interpret all specimens as belonging to a single (morpho-)species, albeit with the understanding that $F$. polyspora might represent an array of several biological species which are impossible to discriminate based on the material at hand. Since the spherical and (sparsely) ornamented form (e.g., Fig. 1.6-1.9) is the most frequent morphotype, we have designated a specimen belonging to this type as holotype (Fig. 1.6).

\section{DISCUSSION}

The Rhynie chert has provided a wealth of information about the structure and composition of Early Devonian terrestrial ecosystems and the morphology and systematic position of the organisms that existed during this period of time. There still remain, however, many examples of Rhynie chert fossils for which the systematic position, and sometimes even their biological affinities, remain unknown. Some of these fossils (e.g., isolated spheres lacking content, fragments of filaments) are impossible to decipher because similar structures occur in multiple groups of modern organisms. Others, however, are characteristic and, despite the limited number of features they possess, can be compared to similar structures in modern organisms. In the case of Frankbaronia polyspora, the co-occurrence in the litter layers and Croftalania venusta-dominated microbial mats together with fungal hyphae and putative algae (Krings et al., 2007) would suggest that the affinities lie with some algal or fungal group.

Affinities.-Among the algal groups that could be compared with Frankbaronia polyspora are the Oedogoniales (Chlorophyceae), freshwater green algae that have unbranched or branched filaments and reproduce asexually by filament fragmentation and zoospore production. Sexual reproduction involves development of a large non-flagellate egg within an oogonium and small multiflagellate sperm within antheridia (Graham and Wilcox, 2000). In Oedogonium Link ex Hirn, 1900, oogonia are mostly intercalary, oval or spherical, and may be of similar size to the $F$. polyspora fossils (e.g., Mahato, 1999; Alberghina et al., 2009). Fossils interpreted as members of the Oedogoniales have been described from the Upper Ordovician of China (Bian and Liu, 1999) and Devonian of North America (Baschnagel, 1966). If the systematic placement of these fossils is correct (e.g., see Zippi, 1998; Riding and Braga, 2005), this would suggest that Oedogoniales may also have occurred in the Rhynie paleoecosystem. However, there is currently no evidence of oedogonialean algae in any of the microbial mats or elsewhere in the Rhynie chert. Arguing against affinities of $F$. polyspora with Oedogoniales is the fact that the latter consistently produce single eggs within an oogonium (Hirn, 1900; Tiffany, 1936). Moreover, we are not aware of any extant member of the Oedogoniales that produces ornamented oogonia. Alternatively, $F$. polyspora might represent some type of unicellular green alga that reproduces asexually by formation of non-motile auto- or aplanospores (see Ettl, 1988). Adding support to this interpretation may be the fact that auto- and aplanospores in one algal cell are usually equal in size and shape (Kaźmierczak and Kremer, 2009). In this scenario, however, the opaque centric inclusions in $F$. polyspora could only be explained as representing a preservational artifact (i.e., coalescence of the spore contents) which seems very doubtful in light of the well-defined outline, consistent shape, and position of these structures in most of the specimens (e.g., Figs. 1.6, 2.1, 2.2), as well as in light of the developmental pattern demonstrated by the specimens illustrated in Figure 3.

Another possible interpretation is that Frankbaronia polyspora represents some type of intercalary or terminal hyphal swelling or propagule of a fungus, which in turn contains the (resting) spores of some kind of intrusive microfungus in the form of the interior spheres. Adding support to this interpretation is the fact that some specimens contain interior spheres attached to hyphal fragments (Fig. 2.7, 2.8, arrows). These interior spheres are different morphologically from typical interior spheres, and thus may in fact represent intrusive fungi. However, preservation of cells and their contents from the Rhynie chert is often remarkably variable within and among specimens (e.g., Wellman et al., 2006). As a result, it is also possible that the morphological differences of the interior spheres illustrated in Figures 2.7 and 2.8 simply represent preservational artifacts. In addition, there is no evidence of an infection site, nor do any of the fossils show more elaborate mycelial systems such as have been documented for other intrusive microfungi from the Rhynie chert (Hass et al., 1994; Krings et al., 2009a, 2010a). It is therefore feasible that some of the interior spheres at some point germinated within the confines of the parental structure, and thus that the hyphal fragments represent germ tubes (see below). Frankbaronia polyspora also has remote similarities with a chytrid

FIGURE 1-Frankbaronia polyspora n. gen. n. sp., putative peronosporomycete oogonia from the Lower Devonian Rhynie chert: 1 , 2, clusters of oogonia within microbial mats, slide P2180, scale $=50 \mu \mathrm{m} ; 3$, spiny oogonia surrounded by cyanobacterial filaments and fungal hyphae, slide P2180, scale $=25 \mu \mathrm{m} ; 4$, empty oogonia near surface of microbial mat, slide P2180, scale $=75 \mu \mathrm{m} ; 5$, detail of 4 , showing oogonium secondarily colonized by other microorganisms (arrows), scale $=25 \mu \mathrm{m} ; 6-11$, selection of specimens showing variability in oogonial shape and surface ornamentation, scale bars $=20 \mu \mathrm{m}$ : 6, holotype, slide P3921; 10, paratype, slide P3925; arrows in 7 and 8 indicate large orifices (possibly attachment points of stout hyphae); arrows in 9 and 11 indicate column-like surface projections, slides P2180 (8), P3922 (7, 9, 11). 


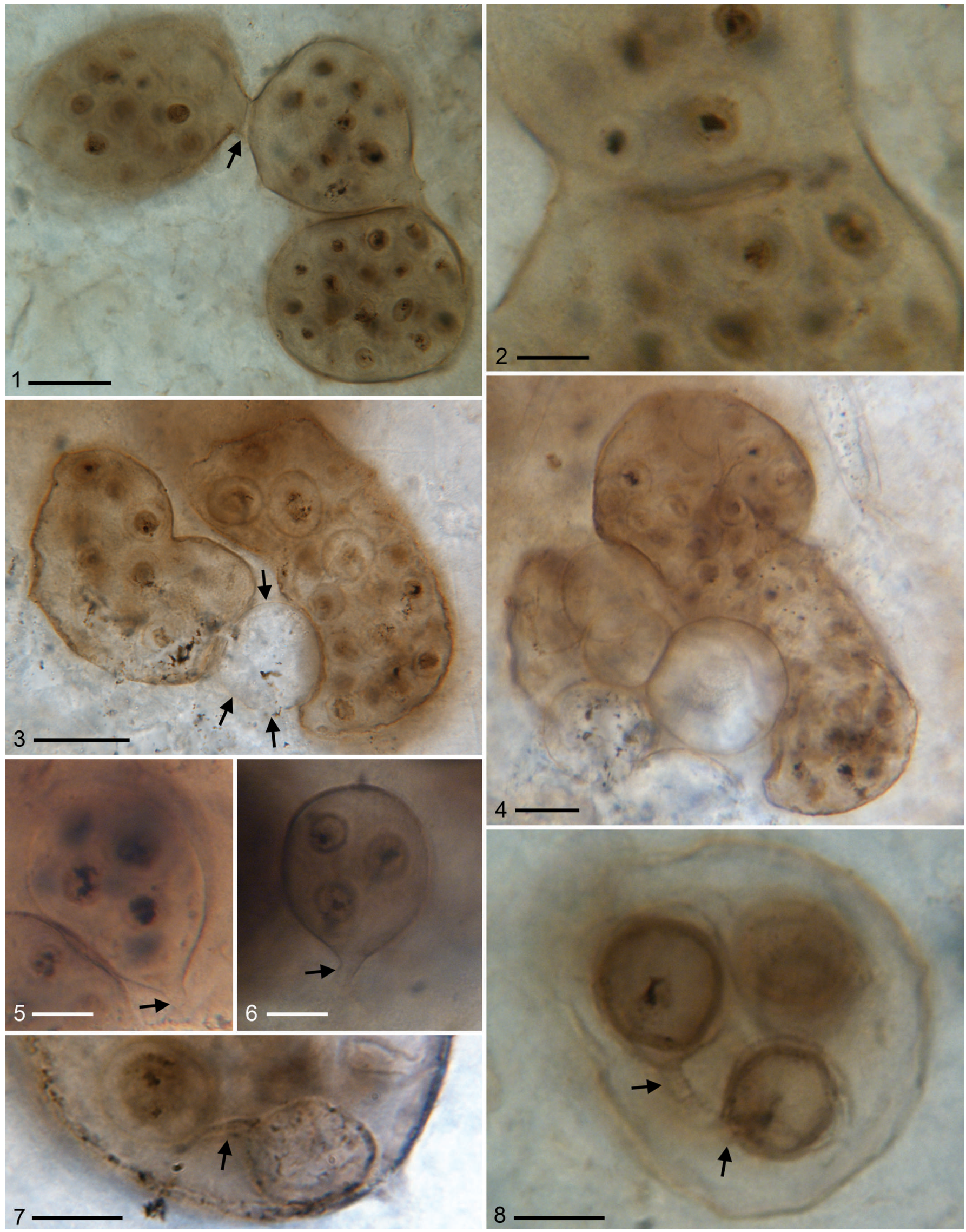

FIGURE 2 - Frankbaronia polyspora n. gen. n. sp., putative peronosporomycete oogonia from the Lower Devonian Rhynie chert: 1 , chain of oogonia, paratype, slide P3911, scale $=25 \mu \mathrm{m} ; 2$, detail of 1 (different focal plane), focusing on oospore morphology and contact area between middle and lower structure, scale $=10 \mu \mathrm{m} ; 3,4$, different focal planes of chain composed of two large, elongate oogonia filled with oospores and (interjacent; arrows in 3) 

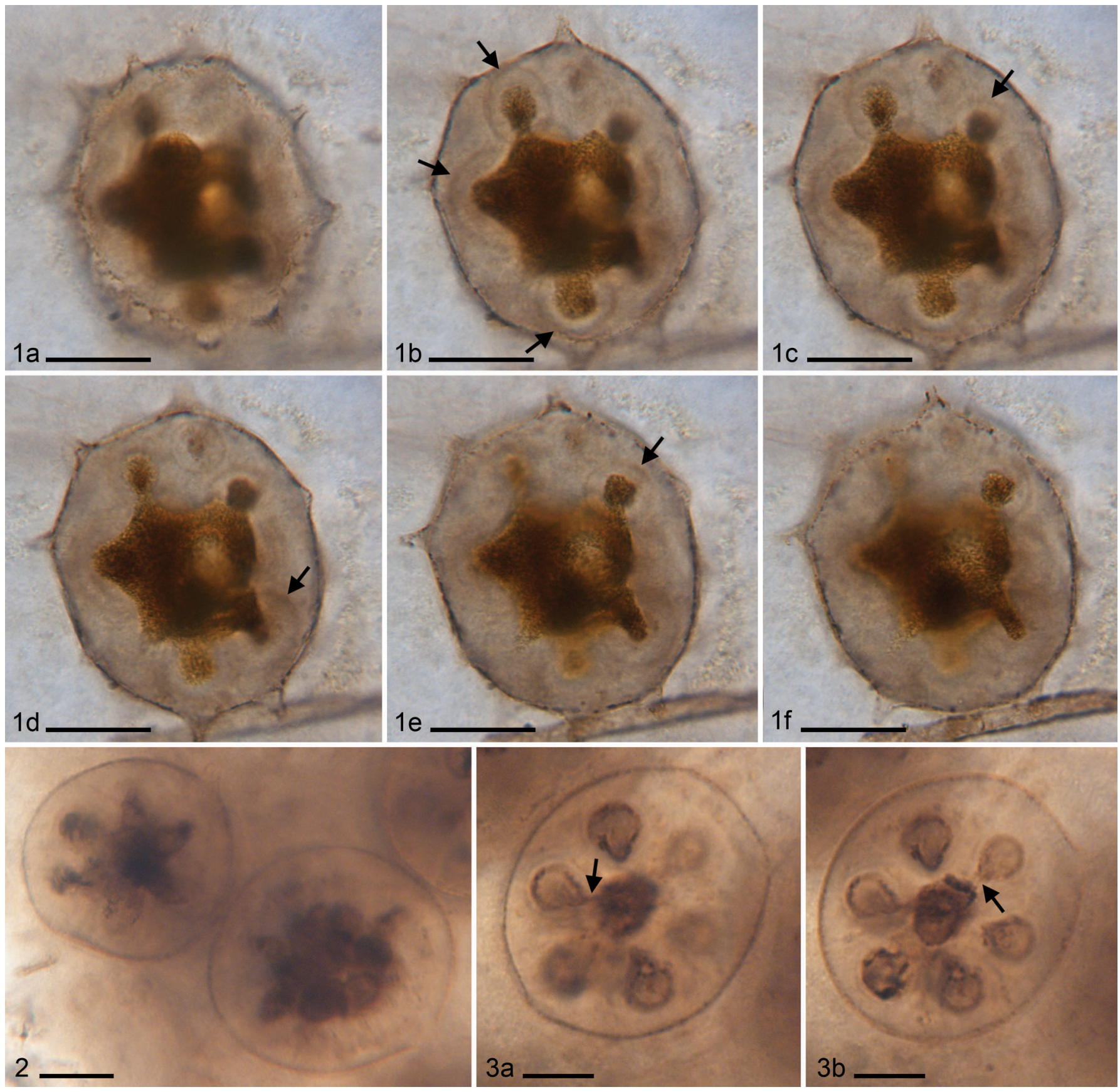

FIGURE 3 - Oospore development in Frankbaronia polyspora n. gen. n. sp.: 1a-f, different focal planes of a specimen showing redistribution of opaque material from centre of parental structure to individual oospores (arrows), slide P3924, scale $=20 \mu \mathrm{m} ; 2$, two other specimens showing similar pattern of redistribution of opaque material as 1 , slide $\mathrm{P} 2180$, scale $=10 \mu \mathrm{m} ; 3 a, b$, later stage of development, note oospore inclusions still connected to centre of oogonium by thread-like structure (arrows), slide P2180, scale $=10 \mu \mathrm{m}$.

(Chytridiomycota) zoosporangium in which the interior spheres are the zoospores. Although the zoospores of most extant chytrids are considerably smaller than the interior spheres of $F$. polyspora, there is at least one form with exceptionally large zoospores that are in the size range of the F. polyspora interior spheres (Karling, 1942). Extant chytrids associated with cyanobacteria, however, grow with rhizoids within individual filaments (see Karling, 1977), not clustered in a mat of filaments. Moreover, all of the interior spheres in $F$. polyspora seem to be in the same stage of development, which would be unusual for a group of chytrids (J. E. Longcore, personal commun., 2007).

smaller spheres that are empty (perhaps immature oogonia), slide 3925 , scale $=30 \mu \mathrm{m}$ (3) and $20 \mu \mathrm{m}(4) ; 5,6$, small oogonia with few oospores, and showing attachment to what appears to be narrow parental hyphae (arrows), slide P2180, scale $=10 \mu \mathrm{m} ; 7$, portion of oogonium containing a morphologically different interior sphere with hyphal appendage (arrow), slide P3901, scale $=10 \mu \mathrm{m} ; 8$, Oogonium containing several spheres with wrinkled walls and particularly large opaque inclusions, note hyphal appendages (arrow) in two of the interior spheres, slide P3923, scale=10 $\mu \mathrm{m}$. 

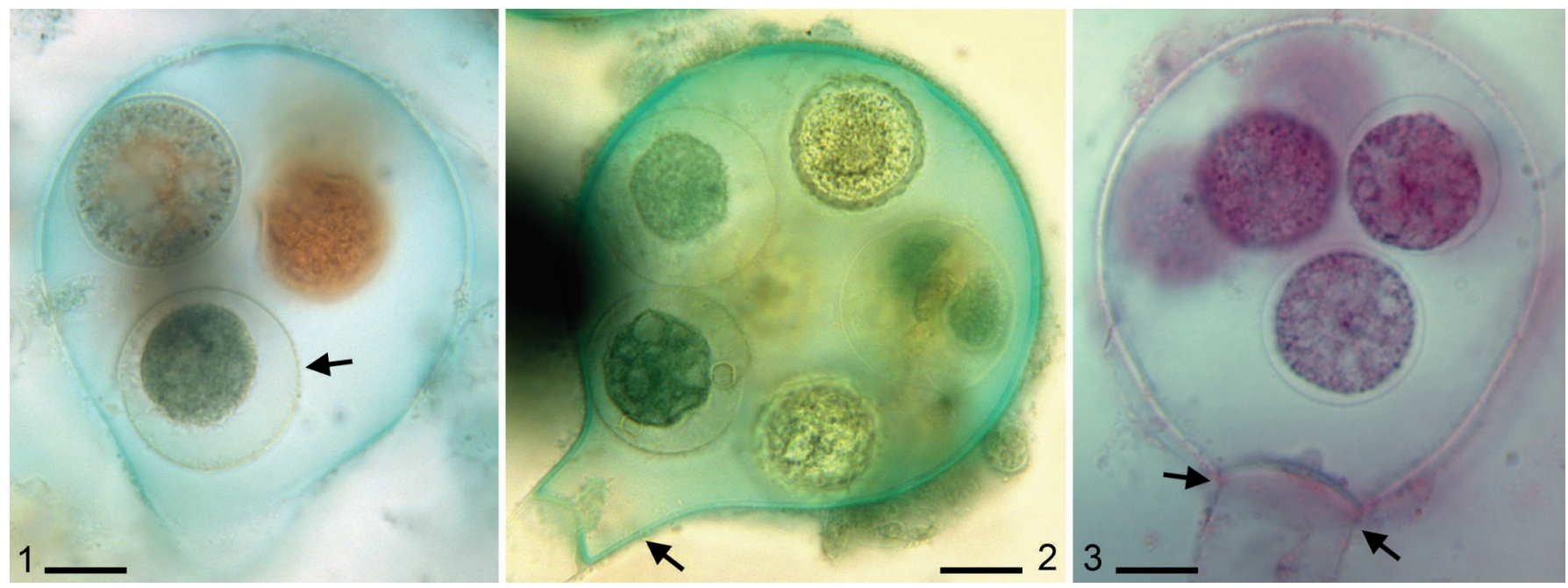

FIgURE 4-1-3, Oogonia of extant Saprolegnia sp. with oospores. Arrow in 1 shows oospore that is identical to those in the fossils. Arrow in 2 indicates truncated extension at base of oogonium, while arrows in 3 show oogonium lacking a basal extension. Scale bars $=10 \mu \mathrm{m}$.

Based on these differences, we interpret Frankbaronia polyspora as representing a polyoosporous oogonium of a member of the Peronosporomycetes, a group of fungus-like organisms that were once aligned with the Fungi, but today are placed in the Kingdom Straminipila (Dick, 2001). Members of the Peronosporomycetes produce flagellate asexual zoospores and sexual oogonia containing oospores that are both structurally and morphologically quite similar to the fossils described here. Perhaps the most compelling modern analogues of $F$. polyspora occur within the Saprolegniales, a mostly saprotrophic order whose members live in both freshwater aquatic and soil habitats (Dick, 1995; Johnson et al., 2002). During sexual reproduction, members of the Saprolegniales, like most other peronosporomycetes, produce terminal or intercalary oogonia that can be quite variable in size and shape and contain one to several naked oospheres (e.g., Pieters, 1915; Kanouse, 1932; Seymore, 1970; Kitancharoen et al., 1995; Prabhuji, 2010). After gametangial fusion, the fertilized oospheres develop into walled oospores (e.g., Fig. 4.1-4.3). Although gametangial fusion in the form of an oogonium-antheridium complex cannot be demonstrated in the fossil $F$. polyspora, the morphology of the fossils, including their contents, is similar in size and shape to the oogonia containing oospores seen in certain extant members of the Saprolegniaceae. Particularly interesting is Saprolegnia multispora B. Paul et Steciow, 2004, which oogonia may be pyriform, spherical, obovate, cylindrical, rarely naviculate or irregular, doliform when intercalary, in shape, and may contain up to 100 oospores that are (10-)12-20(-25) $\mu \mathrm{m}$ in diameter (Paul and Steciow, 2004). With this interpretation, the central opaque area of the interior spheres of $F$. polyspora would represent the ooplast, which is a large membranebound inclusion that forms from the coalescence of vesicles (Seymour, 1970; Howard and Moore, 1970; Howard, 1971).

In many extant peronosporomycetes, including many members of the Pythiaceae (e.g., Pythium Pringsheim, 1858; see Middleton, 1943; Van der Plaats-Niterink, 1981) and certain Saprolegniaceae (e.g., Achlya Nees von Esenbeck [in Carus], 1823; see Johnson, 1949; Johnson et al., 2002), the outer surface of the oogonium wall is variously ornamented. However, direct comparison of the ornamentation of Frankbaronia polyspora with surface ornaments seen in modern peronosporomycetes is difficult since there are indications that many of the surface projections in F. polyspora originally were (considerably) larger, but were broken off, perhaps during maturation of the oogonium or as a result of some external force (e.g., water current). All other bona fide fossils of peronosporomycetes described to date are characterized by ornamented oogonia (see Krings et al., 2011); some Carboniferous forms even possess an ornament that is highly complex and not known in extant forms (Dotzler et al., 2008; Krings et al., 2010b; Strullu-Derrien et al., 2011). For example, prominent antler-like extensions positioned on hollow, column-like or broadly triangular papillations of the oogonial wall occur on the oogonia of Combresomyces cornifer Dotzler et al., 2008, from the Mississippian of France (Dotzler et al., 2008). The surface projections of $F$. polyspora resemble the papillations of the oogonial wall seen in C. cornifer. The only representative of the Peronosporomycetes known previously from the Rhynie chert (i.e., Hassiella monospora Taylor et al., 2006 ) is characterized by an ornament composed of prominent verrucae that is similar to ornaments seen in extant forms.

The cumulative evidence gathered from the fossils renders placement of Frankbaronia polyspora in the Peronosporomycetes as the most plausible option. However, oogniumantheridium complexes have been regarded as the only morphological feature that can be used to safely identify Peronosporomycetes as fossils (Krings et al., 2011). As a result, the consistent absence of antheridia attached to the structures interpreted as oogonia challenges the assignment of $F$. polyspora to the Peronosporomycetes. It is interesting to note in this context, however, that there are also extant Peronosporomycetes (e.g., Pythium anandrum Drechsler, 1930) in which antheridia are usually lacking, and it has been postulated that oospores develop parthenogenetically in these organisms (Van der Plaats-Niterink, 1981).

Another peronosporomycete feature that has not yet been incontrovertibly resolved in Frankbaronia polyspora is the mode of attachment to a subtending hypha or oogonial stalk. In extant peronosporomycetes, the point of attachment of the oogonium often consists of a truncated, collar-like extension that is identical in wall thickness and coloration to the oogonium wall (e.g., in Saprolegnia Nees von Esenbeck [in Carus], 1823; see Fig. 4.2, arrow). This extension occurs in many extant peronosporomycetes (albeit not consistently; e.g., see Fig. 4.3, between the arrows) and has also been described 
in at least two fossils assigned to this group (Dotzler et al., 2008; Strullu-Derrien et al., 2011). Although there is no evidence of the collar-like extension in $F$. polyspora, some oogonia show regions on the wall that might represent attachment points of stout hyphae (Fig. 1.7, 1.8, between the arrows). Other specimens, however, show what appears to be a relatively narrow subtending hypha (Fig. 2.5, 2.6, arrows). It is therefore also possible that $F$. polyspora generally is born on narrow hyphae, and that some of the broken off projections in other specimens actually represent attachment points of the parental hypha.

Development.-The developmental stages of the interior spheres preserved in several specimens of Frankbaronia polyspora (Fig. 3.1-3.3) are difficult to correlate with developmental stages seen in extant peronosporomycetes (e.g., Davis, 1903) because the fossils do not allow for the reconstruction of the entire sequence of events that leads to the formation of the interior spheres. Based on overall configuration it is nevertheless tempting to interpret the specimens shown in Figure 3 as representing the development of oospheres by cleavage of the oogonial cytoplasm (see, e.g., Howard and Moore, 1970). However, the oospheres of virtually all extant peronosporomycetes are naked structures lacking internal differentiation, bounded only by a membrane (Dick, 2001), and thus it is unlikely that oospheres would become preserved in a recognizable form, whereas the interior spheres of $F$. polyspora are internally differentiated and possess a thin but distinct wall (e.g., Figs. 1.6, 2.2, 2.3). There are only two extant genera (i.e., Apodachlyella Indoh, 1939, and Eurychasmopsis Canter et M.W. Dick, 1994) for which the possibility of walled oosphere production has been suggested (Dick, 1986, 2001). It is therefore highly improbable that the interior spheres in $F$. polyspora are oospheres. Rather, we speculate that $F$. polyspora produced a single, large oosphereor coenocentrum-like structure in the centre of the oogonium that became apportioned after fertilization (i.e., in a zygotic state) to form several walled oospores. Adding some support to this hypothesis is the observation that in some extant members of the Saprolegniaceae karyogamy may occur before the cleavage of oospheres (Flanagan, 1970; Dick, 1972). However, we are not aware of any modern polyoosporous peronosporomycete displaying a pattern of oospore genesis similar to that suggested for $F$. polyspora. For example, oosphere and subsequent oospore formation and maturation in polyoosporous Saprolegniales commences by a tonoplast vacuole fusing with cleavage cisternae to form peripheral mounds of presumptive oosphere protoplasts. When the oogonial plasma membrane is finally breached, the oospheres move to the center of the oogonium (e.g., Fletcher, 1978; Dick, 2001). Following oosphere delimitation, a wall begins to form around each oosphere, and wall formation continues after fertilization (e.g., Beakes and Gay, 1978; Johnson et al., 2002). If our interpretations of $F$. polyspora and its development are correct, then the pattern leading to the formation of oospores in this fossil differs from that seen of modern polyoosporous Saprolegniales in at least two fundamental aspects. Firstly, a cleavage of the oogonial protoplasm resulting in the delimitation of individual oospheres is lacking in $F$. polyspora; instead, an oosphere- or coenocentrum-like structure in the centre of the oogonium is apportioned and centrifugally redistributed. The second major difference is based on the timing of oospore wall formation. In the fossil, it is suspected that wall formation is initiated before the apportioning and redistribution of the oogonial protoplasm to the individual oospheres/oospores is completed (Fig. 3.1-3.3).
These fundamental differences in development raise the question as to whether $F$. polyspora might also represent another type of peronosporomycete reproductive structure containing walled propagules (e.g., a zoosporangium with encysted zoospores or a structure producing chlamydospores). Cleavage of zoospore initials in modern peronosporomycetes may be intrasporangial or extrasporangial (Dick, 2001). Intrasporangial zoosporogenesis is characteristic of the Saprolegniales, and the cleavage pattern leading to the formation of zoospores is similar to oogonial cleavage (see above). While the zoospores in most taxa are bounded only by a plasmalemma, some species such as Dictyuchus monosporus Leitg., 1869, and Thraustotheca clavata (de Bary) Humphrey, 1893, are characterized by encystment of the primary zoospores within the sporangium (e.g., Heath and Greenwood, 1970; Johnson et al., 2002). Although zoosporangia containing encysted zoospores may to some degree resemble $F$. polyspora (especially those of Thraustotheca clavata; see Coker and Hyman, 1912; Weston, 1918), the zoosporangia of peronosporomycetes are hardly ever prominently ornamented (for one exception, see Nakagiri et al., 1998). Chlamydospore development is infrequent in the Peronosporomycetes (Dick, 2001). According to Dick (2001), asexual propagules lacking a clearly defined size and/or shape that are released from the mycelium by decay or autolysis of the hyphal system and develop a thick wall may be termed chlamydospores. Since the interior spheres of $F$. polyspora display a clearly defined size, shape, and consistent internal differentiation, they most likely do not represent chlamydospores.

It is interesting to note that the sequence of oospore development suggested above for Frankbaronia polyspora could also be used to explain the consistent absence of antheridia in the fossils. These structures would be attached to the oogonia at earlier stages of development than those depicted by the fossils. As to why these earlier stages have not been recognized as fossils remains unclear. It is possible, however, that the early developmental stages were very fragile (i.e., thin-walled), and thus did not become preserved. If our interpretation of the interior spheres as oospores is correct, then the interior spheres with hypha-like appendages (Fig. 2.7, 2.8) might in fact reflect germination (see above). It has been documented in modern Peronosporomycetes that oospores may germinate within the confines of the parental oogonium if that structure is still intact (e.g., Ziegler, 1953; Duncan, 1977; Johnson et al., 2002).

\section{CONCLUSIONS}

It is becoming increasingly clear that the Rhynie chert Konservat-Lagerstätte contains a varied assemblage of microorganisms, which have contributed substantially to our concept of microbial diversity and mechanisms in shaping and sustaining this Early Devonian terrestrial ecosystem. This concept, however, is based on a relatively small number of examples of complete organisms that can be directly compared to modern analogues (Taylor et al., 2004), while numerous other organisms in the Rhynie chert have received little attention, principally because of their incomplete preservation or lack of diagnostic characters. Currently the Rhynie chert contains the oldest fossil evidence of the Peronosporomycetes (Krings et al., 2011), a group of funguslike organisms that is believed to have existed at least since the Neoproterozoic, some $1.0 \mathrm{Ga}$ ago (Bhattacharya et al., 2009) and perhaps even earlier (Pirozynski, 1976). Although the Rhynie Lagerstätte has been known for 100 years, the discovery of Frankbaronia polyspora proves that this 
freshwater ecosystem is still an important source of new information, especially with regard to microbial life. This fossil also demonstrates that the exquisite preservation in the chert may provide a critical level of structural congruity which can be used to correlate even incomplete fossils with modern analogues. Finally, the availability of multiple specimens provides an opportunity to use patterns of development in determining potential biological affinities and to trace such patterns in time and space.

\section{ACKNOWLEDGMENTS}

This study was supported by funds from the National Science Foundation (EAR 0949947 to TNT and MK), the Deutsche Forschungsgemeinschaft (DFG grant KE 584/13-2 to HK and MK), and the Alexander von HumboldtFoundation (V-3.FLF-DEU/1064359 to MK). The paper greatly benefited from the constructive comments and suggestions of M. Thines (Frankfurt a.M., Germany) and C. Wellman (Sheffield, Great Britain).

\section{REFERENCES}

Alberghina, J. S., C. G. Vélez, and M. S. Vigna. 2009. The oogonial aperture of Oedogonium decipiens var. decipiens (Oedogoniales, Chlorophyta) and its systematic significance. Plant Systematics and Evolution, 280:99-104.

Baschnagel, R. A. 1966. New fossil algae from the Middle Devonian of New York. Transactions of the American Microscopical Society, 85:297-302.

BEAKES, G. W. AND J. L. GAY. 1978. Light and electron microscopy of oospore maturation in Saprolegnia furcata. Transactions of the British Mycological Society, 71:25-35.

BeAKes, G. W. AND S. SEKimoto. 2009. The evolutionary phylogeny of Oomycetes - insights gained from studies of holocarpic parasites of algae and invertebrates, p. 1-24. In K. Lamour and S. Kamoun (eds.), Oomycete Genetics and Genomics: Diversity, Interactions, and Research Tools. John Wiley \& Sons, Inc., Hoboken, New Jersey.

Bhattacharya, D., H. S. Yoon, S. B. Hedges, and D. Hackett. 2009. Eukaryotes, p. 116-120. In S. B. Hedges and S. Kumar (eds.), The Timetree of Life. Oxford University Press, Oxford, UK.

BIAN, L. AND Z. LIU. 1999. Discovery of Late Ordovician algal fossils of Oedogoniales in Jiangxi Province, China. Acta Palaeontologica Sinica, 38:46-49. (In Chinese)

CANTER, H. M. AND M. W. Dick. 1994. Eurychasmopsis multisecunda gen. et sp. nov., a parasite of the suctorian ciliate Podophyra. Mycological Research, 98:105-117.

CAvalier-Smith, T. 1986 The kingdom Chromista: origin and systematics, p. 309-347. In F. E. Round and D. J. Chapman (eds.), Progress in Phycological Research, vol. 4. Biopress Ltd, Bristol.

COKER, W. C. AND O. W. HYMAN. 1912. Thraustotheca clavata. Mycologia, 4:87-90.

Croft, W. N. And E. A. George. 1959. Blue-green algae from the Middle Devonian of Rhynie, Aberdeenshire. Bulletin of the British Museum of Natural History, Geology, 3:341-353.

DAvis, B. M. 1903. Oogenesis in Saprolegnia. Botanical Gazette, 35:233249, 320-349.

Dick, M. W. 1972. Morphology and taxonomy of the Oomycetes, with special reference to Saprolegniaceae, Leptomitaceae, and Pythiaceae. II. Cytogenetic systems. New Phytologist, 71:1151-1159.

Dick, M. W. 1986. A new family and a new genus for two taxa previously assigned to Apodachlyella completa (J. E. Humphrey) H. Indoh (Peronosporomycetidae: Leptomitales). Botanical Journal of the Linnean Society, 93:225-229.

Dick, M. W. 1995. Sexual reproduction in the Peronosporomycetes (chromistan fungi). Canadian Journal of Botany, 73(Supplement 1): S712-S724.

Dick, M. W. 2001. Straminipilous Fungi: Systematics of the Peronosporomycetes Including Accounts of the Marine Straminipilous Protists, the Plasmodiophorids and Similar Organisms. Kluwer Academic Publishers, Dordrecht, $670 \mathrm{p}$.

Dotzler, N., T. N. TAYlor, And M. Krings. 2007. A prasinophycean alga of the genus Cymatiosphaera in the Early Devonian Rhynie chert. Review of Palaeobotany and Palynology, 147:106-111.

Dotzler, N., M. Krings, R. Agerer, J. Galtier, And T. N. TAylor. 2008. Combresomyces cornifer gen. sp. nov., an endophytic peronosporomycete in Lepidodendron from the Carboniferous of central France. Mycological Research, 112:1107-1114.
Dotzler, N., C. Walker, M. Krings, H. Hass, H. Kerp, T. N. TAYlOR, AND R. AgERER. 2009. Acaulosporoid glomeromycotan spores with a germination shield from the 400-million-year-old Rhynie chert. Mycological Progress, 8:9-18.

DRECHSLER, C. 1930. Some new species of Pythium. Journal of the Washington Academy of Sciences, 20:398-418.

DunCAN, J. M. 1977. Germination in vitro of Phythophthora fragariae oospores from infected root tissue. Transactions of the British Mycological Society, 69:391-395.

EDwArDs, D. S. AND A. G. LyON. 1983. Algae from the Rhynie chert. Botanical Journal of the Linnean Society, 86:37-55.

ETTL, H. 1988. Über Definitionen und Terminologie der asexuellen Fortpflanzungszellen bei Grünalgen (Chlorophyta). Archiv für Protistenkunde, 135:17-34.

FAYERS, S. R. AND N. H. TREWIN. 2004. A review of the palaeoenvironments and biota of the Windyfield chert. Transactions of the Royal Society of Edinburgh, Earth Sciences, 94:395-408.

Flanagan, P. W. 1970. Meiosis and mitosis in Saprolegniaceae. Canadian Journal of Botany, 48:2069-2076.

Fletcher, J. 1978. Timing of events during oospore genesis in Saprolegnia diclina. Transactions of the British Mycological Society, 70:417-422.

Graham, L. E. And L. W. Wilcox. 2000. Algae. Prentice Hall, Inc. Upper Saddle River, New Jersey, 640 p.

Hass, H., T. N. TAYlor, AND W. REMY. 1994. Fungi from the Lower Devonian Rhynie chert: mycoparasitism. American Journal of Botany, 81:29-37.

HeAth, I. B. AND A. D. GREenwood. 1970. Wall formation in the Saprolegniales. II. Formation of cysts by the zoospores of Saprolegnia and Dictyuchus. Archiv für Mikrobiologie, 75:67-79.

HIRN, K. E. 1900. Monographie und Iconographie der Oedogoniaceen. Acta Societatis Scientiarum Fennicae, 27:1-394.

HowARD, K. L. 1971. Oöspore types in the Saprolegniaceae. Mycologia, 63:679-686.

HowARD, K. L. AND R. T. MOORE. 1970. Ultrastructure of oogenesis in Saprolegnia terrestris. Botanical Gazette, 131:311-336.

Humphrey, J. E. 1893. The Saprolegniaceae of the United States. Transactions of the American Philosophical Society, 17:1-148.

INDOH, H. 1939. Studies on the Japanese aquatic fungi. I. On Apodachlyella completa sp. nov. with revision of the Leptomitaceae. Science Reports of the Tokyo Bunrika Daigaku, Section B, 4:43-50.

Johnson, T. W. 1949. A new species of Achlya with coiled oogonial stalks. Mycologia, 41:678-685.

Johnson, T. W., R. L. Seymour, And D. E. PAdGetT. 2002. Biology and systematics of the Saprolegniaceae. Published online at: http://dl.uncw.edu/ digilib/biology/fungi/taxonomy\%20and\%20systematics/padgett\%20book/ (last accessed 10, September 2010).

KANOUSE, B. B. 1932. A physiological and morphological study of Saprolegnia parasitica. Mycologia, 24:431-452.

KARLing, J. S. 1942. A new chytrid with giant zoospores: Septochytrium macrosporum sp. nov. American Journal of Botany, 29:616-622.

KARLING, J. S. 1977. Chytridiomycetarum Iconographia. An Illustrated and Brief Descriptive Guide to the Chytridiomycetous Genera with a Supplement of the Hyphochytridiomycetes. J. Cramer, Vaduz, viii + 414 p.

KAŹMIERCZAK, J. AND B. KREMER. 2009. Spore-like bodies in some early Paleozoic acritarchs: Clues to chlorococcalean affinities. Acta Palaeontologica Polonica, 54:541-551.

KerP, H. AND H. HASS. 2004. De Onder-Devonische Rhynie Chert - het oudste en meest compleet bewaard gebleven terrestrische ecosysteem. Grondboor en Hamer, 58:33-50.

KERP, H. AND H. HASS. 2009. Ökologie und Reproduktion der frühen Landpflanzen. Berichte der Reinhold-Tüxen-Gesellschaft, 21:111-127.

Kidston, R. And W. H. LAng. 1921. On Old Red Sandstone plants showing structure, from the Rhynie Chert Bed, Aberdeenshire. Part V. The Thallophyta occurring in the peat-bed; the succession of the plants throughout a vertical section of the bed, and the conditions of accumulation and preservation of the deposit. Transactions of the Royal Society of Edinburgh, 52:855-902.

Kitancharoen, N., K. YuASA, And K. Hatai. 1995. Morphological aspects of Saprolegnia diclina Type 1 isolated from pejerrey, Odonthetes bonariensis. Mycoscience, 36:365-368.

Krings, M., H. Kerp, H. Hass, T. N. TAYlor, And N. Dotzler. 2007. A filamentous cyanobacterium showing structured colonial growth from the Early Devonian Rhynie chert. Review of Palaeobotany and Palynology, 146:265-276.

Krings, M., N. Dotzler, AND T. N. TAYlor. 2009a. Globicultrix nugax nov. gen. et nov. spec. (Chytridiomycota), an intrusive microfungus in fungal spores from the Rhynie chert. Zitteliana A, 48/49:165-170. 
Krings, M., H. Hass, H. Kerp, T. N. Taylor, R. Agerer, And N. DOTZLER. 2009b. Endophytic cyanobacteria in a 400-million-yr-old land plant: A scenario for the origin of a symbiosis? Review of Palaeobotany and Palynology, 153:62-69.

Krings, M., N. Dotzler, J. E. LongCore, And T. N. TAylor. 2010a. An unusual microfungus in a fungal spore from the Lower Devonian Rhynie chert. Palaeontology, 53:753-759.

Krings, M., T. N. TAYlor, J. Galtier, And N. Dotzler. 2010b. A fossil peronosporomycete oogonium with an unusual surface ornament from the Carboniferous of France. Fungal Biology, 114:446-450.

Krings, M., T. N. TAYlor, AND N. Dotzler. 2011. The fossil record of the Peronosporomycetes (Oomycota). Mycologia, 103:445-457.

LEITGEB, H. 1869. Neue Saprolegnieen. Jahrbücher für wissenschaftliche Botanik, 7:357-389.

LÉVESQUE, C. A. 2011. Fifty years of oomycetes - from consolidation to evolutionary and genomic exploration. Fungal Diversity, 50:35-46.

MaнAто, A. K. 1999. A new species of Oedogonium (Chlorophyllaceae, Oedogoniales) from Bihar, India. Feddes Repertorium, 110:173-176.

Middleton, J. T. 1943. The taxonomy, host range and geographic distribution of the genus Pythium. Memoirs of the Torrey Botanical Club, 20:1-171.

NAKAgIRI, A., I. OKAne, AND T. ITO. 1998. Zoosporangium development, zoospore release and culture properties of Halophytophthora mycoparasitica. Mycoscience, 39:223-230.

Nees Von Esenbeck, C. G. 1823. Zusatz. Appended to CARUS, C. G. 1823. Beitrag zur Geschichte der unter Wasser an verwesenden Tierkörpern sich erzeugenden Schimmel- oder Algen-Gattungen. Nova Acta Physico-Medica Academiae Caesareae Leopoldino-Carolinae Germanicae Naturae Curiosum, 11(2):507-522.

Parry, S. F., S. R. Noble, Q. G. Crowley, and C. H. Wellman. 2011 A high-precision U-Pb age constraint on the Rhynie chert KonservatLagerstätte: time scale and other implications. Journal of the Geological Society, London, 168:863-872.

PAul, B. AND M. M. Steciow. 2004. Saprolegnia multispora, a new oomycete isolated from water samples taken in a river in the Burgundian region of France. FEMS Microbiology Letters, 237:393-398.

Pieters, A. J. 1915. New species of Achlya and Saprolegnia. Botanical Gazette, 60:483-490.

PIROZYNSKI, K. A. 1976. Fossil fungi. Annual Review of Phytopathology, $14: 237-246$

PRABHUJ, S. K. 2010. Sexual reproduction in water molds - I: General aspects related to family Saprolegniaceae. International Journal of Plant Reproductive Biology, 2:17-30.

Pringsheim, N. 1858. Beiträge zur Morphologie und Systematik der Algen. 2. Die Saprolegnieen. Jahrbücher für wissenschaftliche Botanik, 1:284-306.

Remy, W., T. N. TAYlor, AND H. HASs. 1994. Early Devonian fungi: a blastocladalean fungus with sexual reproduction. American Journal of Botany, 81:690-702.
Rice, C. A. AND W. A. AshCroft. 2004. The geology of the northern half of the Rhynie basin, Aberdeenshire, Scotland. Transactions of the Royal Society of Edinburgh, Earth Sciences, 94:299-308.

Rice, C. M., N. H. Trewin, AND L. I. Anderson. 2002. Geological setting of the Early Devonian Rhynie cherts, Aberdeenshire, Scotland An early terrestrial hot spring system. Journal of the Geological Society of London, 159:203-214.

RIDING, R. AND J. C. BRAGA. 2005. Halysis Høeg, 1932 - an Ordovician coralline red alga? Journal of Paleontology, 79:835-841.

SEymour, R. L. 1970. The genus Saprolegnia. Nova Hedwigia, 19:1-124.

Strullu-Derrien, C., P. Kenrick, J. P. Rioult, and D. G. Strullu. 2011. Evidence of parasitic Oomycetes (Peronosporomycetes) infecting the stem cortex of the Carboniferous seed fern Lyginopteris oldhamia. Proceedings of the Royal Society, Series B, 278:675-680.

TAYlOR, T. N., W. REMY, AND H. HASs. 1992. Fungi from the Lower Devonian Rhynie chert: Chytridiomycetes. American Journal of Botany, 79:1233-1241.

TAYlOR, T. N., W. REMY, H. HASS, AND H. KerP. 1995. Fossil arbuscular mycorrhizae from the Early Devonian. Mycologia, 87:560-573.

TAYlor, T. N., S. D. Klavins, M. Krings, E. L. TAYlor, H. KeRP, AND H. HASs. 2004. Fungi from the Rhynie chert: A view from the dark side. Transactions: Earth Sciences, 94:457-473.

TAylor, T. N., H. Hass, H. Kerp, M. Krings, and R. T. Hanlin. 2005. Perithecial ascomycetes from the 400 million year old Rhynie Chert: An example of ancestral polymorphism. Mycologia, 97:269-285.

TAYlor, T. N., M. Krings, AND H. KERP. 2006. Hassiella monospora gen. et sp. nov., a microfungus from the 400 million year old Rhynie chert. Mycological Research, 110:628-632.

Tiffany, L. H. 1936. The Oedogoniales. Botanical Review, 2:456-473.

TrEwIN, N. H. AND C. M. RICE, eds. 2004. The Rhynie hot-spring system: geology, biota and mineralisation. Transactions of the Royal Society of Edinburgh, Earth Sciences, 94:285-521.

VAN DER PlaATs-NiterinK, A. J. 1981. Monograph of the genus Pythium. Studies in Mycology, 21:1-242.

Wellman, C. H. 2006. Spore assemblages from the Lower Devonian 'Lower Old Red Sandstone' deposits of the Rhynie outlier, Scotland. Transactions of the Royal Society of Edinburgh, Earth Sciences, 97:167-211.

Wellman, C. H., H. KerP, AND H. Hass. 2006. Spores of the Rhynie chert plant Aglaophyton (Rhynia) major (Kidston and Lang) D.S. Edwards, 1986. Review of Palaeobotany and Palynology, 142:229-250.

Weston, W. H. 1918. The development of Thraustotheca, a peculiar water-mould. Annals of Botany, 32: 155-173.

ZIEGLER, A. W. 1953. Meiosis in Saprolegniaceae. American Journal of Botany, 40:60-66.

ZIPPI, P. A. 1998. Freshwater algae from the Mattagami Formation (Albian), Ontario: Paleoecology, botanical affinities, and systemjatic taxonomy. Micropaleontology, 44(Supplement 1):1-78.

ACCEPTED 26 SEPTEMBER 2011 